2020 Global Marketing Conference at Seoul Proceedings: 632-636 (November 2020)

https://doi.org/10.15444/GMC2020.05.06.01

\title{
THE DIFFERENT SHADES OF BRAND HATE: A QUALITATIVE APPROACH
}

\author{
José Pereira, Instituto Universitá rio de Lisboa (ISCTE-IUL) and Business Research \\ Unit (BRU-IUL), Portugal ${ }^{1}$ \\ Sandra Loureiro, Instituto Universitá rio de Lisboa (ISCTE-IUL) Portugal ${ }^{2}$
}

\begin{abstract}
While Brand Love has been extensively studied, Brand Hate is still in the early stages of its theoretical development. Aiming to reduce that gap, this project has three main goals: first, conduct a thorough literature review, seeking to consolidate what has been written about the concepts of love, hate, brand love, brand hate and several supportive elements such as emotions, consumer-brand relationships, brand and anti-brand communities; second, perform and code multiple semi-structured/in-depth interviews, analyse and discuss the Portuguese costumer's perception on the topic and link it with academia; third, build a literate crossing between Marketing and Linguistics that can be used by future studies. Supporting these objectives is the Constructivist Grounded Theory methodology. Among the findings generated by this process, seven facets were uncovered: emotions are essential to the shopping experience; there is an occasional contemporaneity between diverse elements of Active Brand Hate; Negative Past Experiences was the most cited antecedent of Brand Hate; it is possible to turn Brand Hate into neutral or positive relationships, but so is the inverse; Negative Double Jeopardy should be divided into parcels; Oppositional Brand Loyalty ought be tested as another antecedent; there are dissimilar types of Brand Hostages.
\end{abstract}

Keywords: brand hate, emotions, consumer-brand relationships, anti-branding communities

\section{INTRODUCTION}

The illustrious marketing flank of academia has been an active agent at the forefront of evolving efforts to deepen the knowledge about consumer-brand relationships. First, with a centuries-old transactional mindset that unfolded into a relational approach (Morgan and Hunt, 1994), which in turn called for the creation of ground-breaking intellectual fields such as relationship marketing (Gummesson, 2017), scholars started to understand how important it was to build unconventional connections between social and behavioural sciences. Despite that growing trend to connect disciplines like marketing and psychology, there are still some academics who consider that such method should be carefully applied, or the studied topics would generate questionable/biased conclusions (Zarantonello et al., 2016). In this vein, the current study has three major objectives. First, conduct a thorough literature review, seeking to consolidate what has been written about the concepts of love, hate, brand love, brand hate and several supportive elements such as emotions, consumer-brand relationships, brand and anti-brand communities. Second, perform and code multiple semi-

\footnotetext{
${ }^{1}$ jampa@iscte-iul.pt

2 sandramloureiro@netcabo.pt
} 
structured/in-depth interviews, analyse and discuss the Portuguese costumer's perception on the topic and link it with academia. Third, build a literate crossing between Marketing and Linguistics that can be used by future studies. Supporting these objectives is the Constructivist Grounded Theory methodology.

\section{THEORETICAL BACKGROUND}

Contradicting an entrenched human tendency to mainly focus on the negative side of the natural and artificial ingredients that compose both existential and everyday aspects of life (Baumeister, 2001), scientific research has focused more on the positive emotions and relations. Corroborating this argument is the abundance of studies conducted within the realm of positive customer-brand interactions, with brand love, for example, being top among them, opening all of its relatable factors to various reviews (Palusuk et al., 2019). In what can be considered a neglected endeavour towards understanding consumer behaviour, concepts like brand hate, what causes it, what it causes (ex: negative word-of-mouth) and how can companies work around such issues have been avoided (Zarantonello et al., 2016); Hegner et al., 2017). Another relevant takeaway from having conducted a scrupulous literature review are the fascinating and emerging motifs of anti-brand communities, which can have severely harmful effects (Romani, Grappi, Zarantonello and Bagozzi, 2015) that supersede probrand online forums or fan-made sites, but can still be countered if the companies who provide the products or services pay attention to what customers are saying and attempt to convert them or intelligently manage a brand-customer divorce.

The hateful connection between labels and their customers is generally defined by Bryson et al., (2013:395) as "...an intense negative emotional affect towards the brand.". Besides that, four probable antecedents were signalled: a) countryof-origin of the trademark (customers avoiding to buy products from a certain corporation because it comes from an economically, political or military offending nation (Khan and Lee, 2014)); b) consumer dissatisfaction, which is portrayed as products not meeting the expected criteria; c) negative stereotypes of people who use commodities from a specific brand; d) corporate social performance, which means failing to do "...the integration of the principles of social responsibility, the processes of social responsiveness, and the policies developed to address social issues." (Clark, 2000:369; Wartick and Cochran, 1985) in a producing company. Considering that the preceding literature was a reasonable launching pad but, somehow, still painted an incomplete image, Zarantonello, Romani, Grappi and Bagozzi (2016) issued a comprehensive study where lacunas of previous analysis were identified (regarding psychological notions) and underscored possible antecedents and outcomes that could have been overlooked by marketing, consumer-brand relationship and behavioural analysts - corporate wrongdoing, violation of expectations (usually met with Approach Strategies and Attack Strategies) and taste system (sometimes answered with Avoidance Strategies); and outcomes (complaining (Public - government, companies; Private family and friends), Negative Word of Mouth, patronage reduction). Posteriorly, the scholars Hegner et al. (2017) progressed to a different identification: negative past experiences (NPE), symbolic/image incongruity (SII) and ideological incompatibility (II) as determinants/antecedents of BH, and brand avoidance (BAV), NWOM and brand retaliation (BR) as its outcomes. Regarding II, it can be considered an enriched version of moral violations - companies compromising their image not only because they disrespect the environment or the workforce but, in exceptional cases, due to what they 
stand for, such as gun proliferation (ex: gun-haters reaction to the National Rifles Association (Park et al.,2013)).

Pondering about the nature of the research questions (How may brand hate be conceptualised? What are the facets of brand hate? Do brand love and brand hate share a similar prototype?), the limited existence of secondary data and the various instruments available to collect primary information, a non-standardised $>$ one-on-one $>$ face-to-face interview was the prime choice. A research interview can be defined as a deliberate and in-person conversion between at least two people, with the interviewer asking unambiguous questions to a focused and responsive second party (Saunders et al., 2016). Still, regarding the process of obtaining contrived data, it is adequate to detail that, sometimes, the right decision is not to elect only one type of interviewing mechanism. In the case of this qualitative investigation, the final product is a combination of aspects from the semi-structured interviews (SSI) and in-depth interviews (IDI) (informal events organised in advance by the investigator, at a location and time convenient to the interviewees, embedded in their daily work/private life; existence of an interview schedule (McIntosh et al., 2015) comprised of preordained open-ended questions that can have their order and rationale altered, with further queries emerging from the evolving dialogue (a participator has the opportunity to briefly digress around the main topic); duration inferior to thirty minutes; individual as elegantly put by DiCicco-Bloom and Crabtree (2006) and partly supported by Saunders, Lewis and Thornhill (2016).

\section{METHODOLOGY}

The present study is lent partial methodological support by a system that branched out of the Grounded Theory (Glaser and Strauss (2006[1967]), found to be more appropriate to the data and researcher analysing it: The Constructivist Grounded Theory (CGT). Entrenched in relativist epistemologies and pragmatism: it upholds that theories are not uncovered but constructed (Charmaz, 2008); takes into account the researcher's ontological stand (learning about and depicting the studied world is a non-linear problem that encases a socially assembled reality), perspectives/reflexivity and the practises within this research's context; and, maybe the most surprising but germane point to be made when fending off classical theorists - a CGT report does not begin without having read and grilled the main articles about the subjects being investigated. This has been seen to be vital, as doing it without grounding in existing knowledge could lead to superficial and obvious pattern recognition, stripping the researcher of the conceptual leverage (Glaser, 1978).

\section{MAJOR RESULTS}

Coding the interviews (deconstructing the data, questioning what is happening in each small segment and to what theoretical category does it belong to (Charmaz, 1983)) can be done in two dissimilar ways: manually or with the aid of CAQDAS (ComputedAssisted Qualitative Data Analysis Software). For the sake of trying a yet novel approach, the choice has fallen on the second option (with ATLAS.ti being preferred over NVivo). Since the beginning of its use, there was an immersive experience of wrestling with the meaning, interpretation and refinement of every code, plus the identification and justification of relationships (either by groups or graphical networks), once again putting the purists' mind at ease (Goulding, 2017). Gioia, Corley and 
Hamilton (2012)'s first-order (informant-centric terms) and second-order coding (researcher-centric concepts) was the selected coding methodology to ensure exploratory rigor.

Several facets of Brand Hate were identified: F1 - Shopping with emotions (emotions are essential to the shopping experience); F2 - The cautionary tales of APS, its brother NWOM (ATS) and AVS (there is an occasional contemporaneity between diverse elements of Active Brand Hate); F3 - And the Golden Raspberry award for worst BH antecedent goes to...NPE, not SII or II (Negative Past Experiences was the most cited antecedent of Brand Hate); F4 - Vinyl's side A: possibility to recuperate from BH... and side B: odds of sinking into it (it is possible to turn Brand Hate into neutral or positive relationships but so is the reverse); F5 - NDJ and the national chapter of customers (Negative Double Jeopardy should be divided into parcels); F6 - Possible new element of SII: Oppositional Brand Loyalty (OBL ought to be tested as another antecedent of $\mathrm{BH}$ ); F7 - Release the Brand Hostages...if they want (there are dissimilar types of Brand Hostages - at least two of them: the unwilling and hateful, the complaining but willing).

\section{CONCLUSIONS}

The topic on brand hate twofold. First, this research gives an extensive overview of the literature on the topic. Second, following the protocol of Ground theory and conducting interviews, point out facets of brand hate, which where compared to past research and discussed what has been already presented in past research and the new ones that emerge. These contributes give a new light on the topic which may be consolidated in other contexts and using qualitative approaches.

Overall, four main conclusions is possible to express: (i) Trust is critical in mitigating negative emotions, (ii) Negative or positive message framing can be used to minimize or maximize brand hate, (iii) Luxury brands lying about ethical production may lead to an erudite type of brand hate, (iv), As love and hate can coexist, so can brand love and brand love (ex: hating a brand but loving the products). In the end, a research question emerges for future research: If Relationship strength works as a buffer to counter negativity, how elastic is Brand Love before it dives into BH?

\section{REFERENCES}

Baumeister, R. F., Bratslavsky, E., Finkenauer, C. \& Vohs, K. D. 2001. Bad is stronger than good. Review of General Psychology, 5 (4): 323-370.

Bryson, D., Atwal. G., \& Húlten, P. 2013. Towards the conceptualisation of the antecedents of extreme negative affect towards luxury brands. Qualitative Market Research: An International Journal, 16 (4): 393-405.

Charmaz, K. 1983. The grounded theory method: An explication and interpretation. In R. Emerson (Eds.), Contemporary field research: A collection of readings: 43-51. Boston, MA: Little Brown.

Charmaz, K. 2008. Constructionism and the grounded theory method. In J. Holstein \& J. Gubrium (Eds.), Handbook of constructionist research: 397-411. New York, NY: Guilford Press.

Clark, C. 2000. Differences between public relations and corporate social responsibility: An analysis. Public Relations Review, 26 (3): 363-380.

DiCicco-Bloom, B. \& Crabtree, B. F. 2006. The qualitative research interview. Medical 
Education, 40(4): 314-321.

Gioia, D. A., Corley, K. \& Hamilton, A. 2012. Seeking qualitative rigor in inductive research. Organizational Research Methods, 16 (1): 15-31.

Glaser, B. 1978. Theoretical sensitivity: Advances in the methodology of grounded theory. Mill Valley, CA: Sociology Press.

Glaser, B. \& Strauss, A. 2006 [1967]. The discovery of grounded theory: Strategies for qualitative research. New York, NY: Aldine.

Goulding, C. 2017. Navigating the complexities of grounded theory research in advertising. Journal of Advertising, 46 (1): 61-70.

Gummesson, E. 2017. From relationship marketing to total relationship marketing and beyond. Journal of Services Marketing, 31 (1):16-19.

Hegner, S. M., Fetscherin, M., \& Delzen, M. V. 2017. Determinants and outcomes of brand hate. Journal of Product \& Brand Management, 26 (1): 13-25.

Khan, M. A., \& Lee, M. S. W. 2014. Prepurchase determinants of brand avoidance: The moderating role of country-of-origin familiarity. Journal of Global Marketing, 27 (5): 329-343.

McIntosh, M. J. \& Morse, J. M. 2015. Situating and constructing diversity in semistructured interviews. Global Qualitative Nursing Research, 2: 1-12.

Morgan, R. M., \& Hunt, S. D. 1994. The commitment-trust theory of relationship marketing. Journal of Marketing, 58(3): 20-38.

Palusuk, N., Koles, B. \& Hasan, R. 2019. All you need is brand love: A critical review and comprehensive conceptual framework for brand love. Journal of Marketing Management, 35 (1-2): 97-129.

Park, C., Eisingerich, A. \& Park, J. 2013. Attachment-aversion (AA) model of customer-brand relationships. Journal of Consumer Psychology, 23 (2): 229-248.

Romani, S., Grappi, S., Zarantonello, L. \& Bagozzi, R. 2015. The revenge of the consumer! How brand moral violations lead to consumer anti-brand activism. Journal of Brand Management, 22 (8): 658-672.

Saunders, M. N. K., Lewis, P. \& Thornhill, A. 2016. Research methods for business students (7th ed.). Harlow: Pearson Education.

Wartick, S. L. \& Cochran, P. L. 1985. The evolution of the corporate social performance model. Academy of Management Review, 10 (4): 758-769.

Zarantonello, L., Romani S., Grappi S. \& Bagozzi, R. P. 2016. Brand hate. Journal of Product \& Brand Management, 25 (1): 11-25. 